\title{
PREDIKSI LAJU PERAMBATAN RETAK MELAR PADA BAJA AUSTENITIK 316L MENGGUNAKAN DATA UJI MELAR DAN METODE NSW
}

\author{
I Made Wicaksana \\ Ekaputra \\ Tenaga Pengajar (Dosen) \\ Universitas Sanata Dharma \\ Jurusan Teknik Mesin \\ made@usd.ac.id
}

\begin{abstract}
In this study, an experimental creep crack growth rate (CCGR) of austenitic steel AISI 316L was predicted from the creep constant values and Nibkin Smith Webster (NSW) method. The experimental CCGR data were obtained from the CCG test under four different load conditions ranging from 6000 to $7000 \mathrm{~N}$ at $525^{\circ} \mathrm{C}$. The creep constants, A and $\mathrm{n}$ were obtained from the uniaxial creep rupture test under various load conditions, ranging from 180 to $225 \mathrm{Mpa}$ at $525{ }^{\circ} \mathrm{C}$. The creep constants were determined both from the minimum and average creep strain rate data. By applying the creep constants and NSW method, the predicted CCGR curve was generated and compared with the experimental CCGR curve. The result showed that the predicted CCGR curve based on the minimum creep strain rate data was found to be close to the experimental CCGR curve. The significant portion of creep crack growth's lifetime of austenitic steel AISI 316L was occupied by the crack propagation (steady stage) period rather than crack initiation and/or fracture periods. In addition, plane stress and strain conditions could also be determined from the predicted CCGR curve. It was observed that the experimental CCGR curve was located near the plane strain condition where no deformation occurred in the lateral direction.
\end{abstract}

Keywords: Austenitic Steel AISI 316L, CCGR, Creep Rupture, NSW.

\section{PENDAHULUAN}

Baja austenitik AISI 316L adalah salah satu kandidat material yang sangat cocok digunakan untuk komponenkomponen yang beroperasi pada lingkungan kerja yang ekstrim, khususnya yang bersifat korosif dan temperature yang cukup tinggi seperti pada pembangkit listrik tenaga gas dan uap (PLTGU) dan pembangkit listrik tenaga nuklir (PLTN) [1-2]. Dengan komposisi kimia terbesar diantaranya adalah Chromium (Cr), Molybdenum (Mo), dan Nickel (Ni), serta komposisi Carbon (C) yang rendah ( $<0.03 \mathrm{C}$ wt-\%), menjadikan AISI 316L memiliki beberapa sifat mekanis yang unggul, diantaranya tahan pada lingkungan korosif dan suhu tinggi, sifat mampu bentuk dan las yang baik, serta tidak dapat dimagnetkan [3-6].

Pada kondisi temperatur yang tinggi dan pembebanan yang konstan, suatu material dapat mengalami salah suatu bentuk kegagalan yang dinamakan dengan kegagalan melar (creep rupture). Kegagalan melar yang terjadi pada suatu struktur perlu diperhitungkan dengan seksama dan hati-hati, karena prosesnya terjadi dalam waktu yang cukup lama dan pada periode tertentu akan gagal secara tiba-tiba. Kegagalan melar dalam mekanisme perpatahan (fracture mechanics) diklasifikasikan sebagai jenis perpatahan yang bergantung pada waktu (time-dependent fracture mechanics) [6]. Gambar 1 menunjukan kurva regangan terhadap fungsi waktu yang merepresentasikan kurva melar secara umum. Pada kurva tersebut, terdapat tiga tahapan proses, yaitu tahap pertama (primary stage), kedua (secondary stage), dan ketiga (tertiary stage). Pada tahap pertama material akan mengalami penguatan atau disebut dengan strain hardening, lalu dilanjutkan dengan tahap kedua yaitu tahap stabil atau disebut juga dengan steady stage, dan terakhir dilanjutkan dengan tahap percepatan atau disebut juga dengan acceleration stage, dimana material akan mengalami patah secara tiba-tiba. Dilihat dari 
proporsi waktu prosesnya, tahapan kedua pada kurva melar memiliki presentase waktu terbesar, dimana hampir sebagian besar proses waktu melar terjadi pada tahap ini.

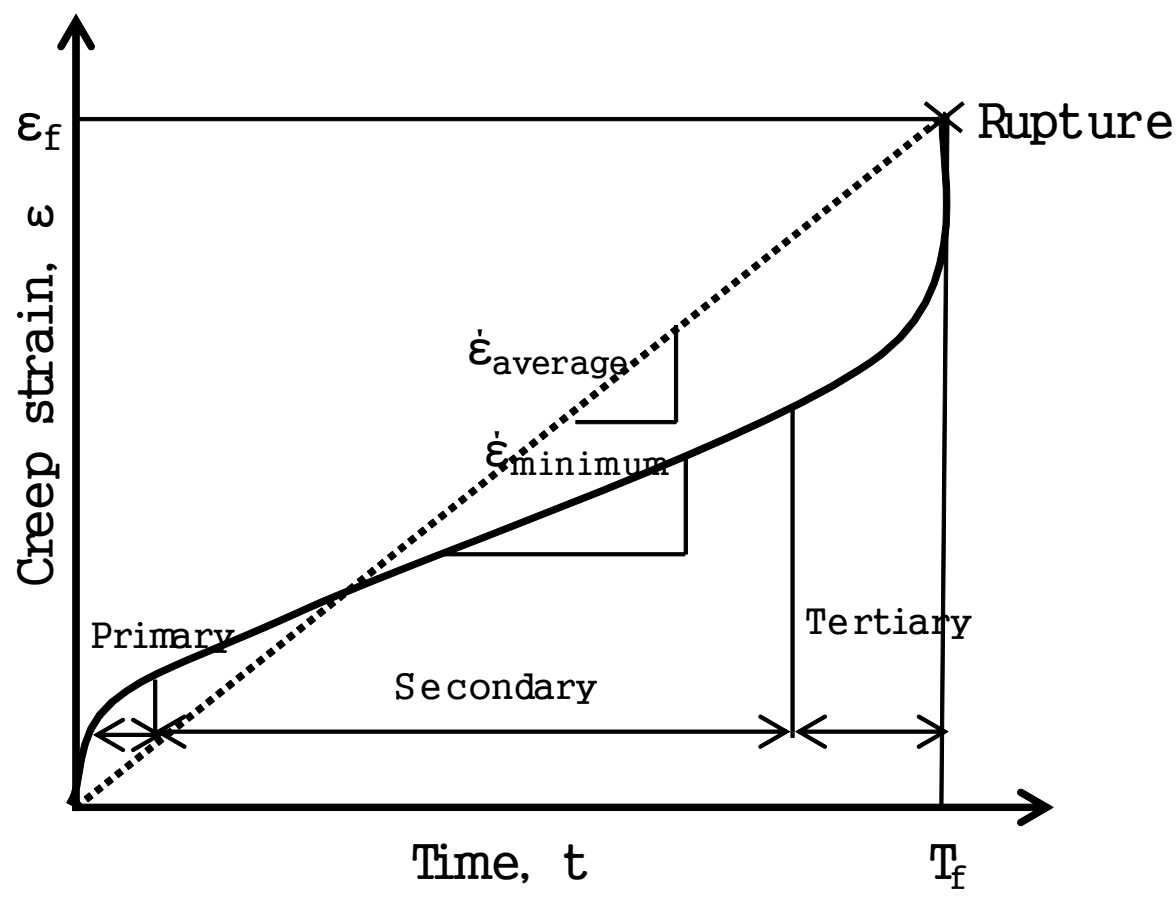

Gambar 1: Kurva melar.

Setelah melewati tahap kedua, material akan mengalami percepatan perambatan retak dan akhirnya patah. Saat perambatan retak mencapai tahap ketiga, maka dalam waktu yang sangat singkat material akan patah secara tiba-tiba. Oleh sebab itu laju perambatan retak pada tahap kedua perlu diprediksi sebelum terjadinya percepatan retak pada tahap ketiga [7-9]. Dalam melakukan perhitungan laju perambatan retak melar (creep crack growth rate) diperlukan suatu pengujian yang dinamakan dengan pengujian perambatan retak melar (creep crack growth), yang kemudian dianalisis menggunakan suatu parameter yang disebut dengan parameter $C^{*}$ [7-8]. Kendala yang sering dihadapi dalam melakukan pengujian perambatan retak melar diantaranya adalah waktu yang tepat untuk menghentikan pengujian sebelum material mencapai tahap ketiga dan kesulitan dalam penentuan kondisi tegangan pada permukaan baik berupa kondisi plane stress atau strain. Oleh sebab itu, sebagai salah satu bentuk pendekatan, beberapa penelitian telah dilakukan pada beberapa material untuk memprediksi laju perambatan retak hanya dengan menggunakan konstanta melar (creep constants) yang diperoleh dari data pengujian melar (uniaxial creep rupture), dan dirumuskan menggunakan metode Nibkin Smith Webster atau lebih dikenal dengan metode NSW [10-15].

Dalam artikel ini, sejumlah data laju perambatan retak melar dan konstanta melar pada baja austenitik AISI 316L diperoleh masing-masing dari pengujian perambatan retak melar dan melar. Pengujian perambatan retak melar diperoleh berdasarkan kondisi pembebanan konstan yang bervariasi antara 6000 hingga $7000 \mathrm{~N}$ dan temperature konstan sebesar $525{ }^{\circ} \mathrm{C}$. Sedangkan pada pengujian melar, pengujian dilakukan dengan pembebanan konstan yang bervariasi antara 180 hingga $225 \mathrm{MPa}$ dan temperature konstan sebesar $525^{\circ} \mathrm{C}$. Dari data pengujian melar, nilai konstanta melar diperoleh dan digunakan untuk menghitung prediksi laju perambatan retak melar menggunakan metode NSW. Prediksi laju perambatan retak melar kemudian dibandingkan dengan data eksperimen laju perambatan retak melar yang terjadi pada baja austenitik AISI 316L.

\section{METODE DAN BAHAN}

Komposisi kimia untuk baja austenitik AISI 316L secara keseluruhan dapat dilihat pada tabel 1. Spesimen yang digunakan dalam pengujian berupa batang logam yang dibentuk melalui proses hot rolling hingga terbentuk plat dengan ketebalan $10 \mathrm{~mm}$. Spesimen yang digunakan untuk pengujian melar berbentuk silinder dengan panjang $30 \mathrm{~mm}$ dan diameter $6 \mathrm{~mm}$. Pengujian melar mengikuti prosedur yang ada pada standar ASTM E139. Pengujian melar dilakukan dengan beberapa variasi pembebanan konstan antara 180 hingga $225 \mathrm{MPa}$ pada temperature $525{ }^{\circ} \mathrm{C}$. Temperatur pada saat pengujian dipertahankan pada batas yang diizinkan yaitu \pm 2 
${ }^{\circ} \mathrm{C}$. Berdasarkan kurva melar yang diperoleh dari masing-masing pembebanan, nilai konstanta melar, $A$ dan $n$ diperoleh dengan menerapkan persamaan Norton pada kurva logaritmik tegangan sebagai fungsi laju regangan melar (creep strain rate). Laju regangan melar diperoleh dengan menarik garis regresi menggunakan metode linear square fitting method (LSFM), masing-masing pada tahap kedua/regangan melar minimum (minimum creep strain rate) dan keseluruhan tahap/regangan melar rata-rata (average creep strain rate) seperti yang terlihat pada gambar 1 . Nilai Konstanta melar, $A$ dan $n$ untuk masing-masing laju regangan melar minimum dan rata-rata dapat dilihat pada tabel 2.

Sebagai data acuan, pengujian perambatan retak melar (CCG) dilakukan dengan menerapkan pembebanan yang bervariasi antara 6000 hingga $7000 \mathrm{~N}$ pada temperatur $525{ }^{\circ} \mathrm{C}$. pengujian dilakukan mengikuti prosedur yang ada pada standar ASTM E1475 [16]. Spesimen yang digunakan dalam pengujian berjenis compact tension (CT), seperti yang terlihat pada gambar 2. Pada saat pengujian, perubahan panjang spesimen akibat deformasi diukur menggunakan linear variable displacement transducer (LVDT). Perambatan retak pada spesimen CT diukur menggunakan metode direct current potential drop (DCPD). Tegangan output yang diperoleh melalui metode DCPD dikonversi menjadi panjang retakan menggunakan persamaan Johnson [16] sebagai berikut:

$$
a=\frac{2 W}{\pi} \cos ^{-1} \frac{\cosh \left(\pi Y_{0} / 2 W\right)}{\cos V / V_{0}\left[\cosh ^{-1}\left\{\left(\cosh \left(\pi Y_{0} / 2 W\right) / \cos \left(\pi a_{0} / 2 W\right)\right)\right\}\right]}
$$

dimana $a$ = panjang retak, $a_{o}=$ panjang retak awal, $V=$ tegangan output, $V_{o}=$ tegangan output awal, $W=$ lebar spesimen, and $Y_{o}=$ jarak antara kawat tegangan output pada spesimen CT.

Laju perambatan retak melar yang diperoleh dari pengujian perambatan retak melar dikalkulasi dan dianalisis menggunakan parameter $C^{*}$ [7-8]. Relasi antara laju perambatan retak dan parameter $C^{*}$ dirumuskan berdasarkan persamaan power sebagai berikut,

$$
\frac{d a}{d t}=B\left(C^{*}\right)^{q}
$$

dimana nilai $B$ dan $q$ masing-masing adalah konstanta laju perambatan retak.

Tabel 1: Komposisi kimia dari AISI 316L (wt.\%).

\begin{tabular}{|c|c|c|c|c|c|c|c|c|c|}
\hline $\mathrm{Fe}$ & $\mathrm{C}$ & $\mathrm{Si}$ & $\mathrm{Mn}$ & $\mathrm{P}$ & $\mathrm{S}$ & $\mathrm{Cr}$ & $\mathrm{Ni}$ & $\mathrm{Mo}$ & $\mathrm{Fe}$ \\
\hline bal. & 0.022 & 0.47 & 1.899 & 0.046 & 0.008 & 17.501 & 10.018 & 2.096 & 67.290 \\
\hline
\end{tabular}
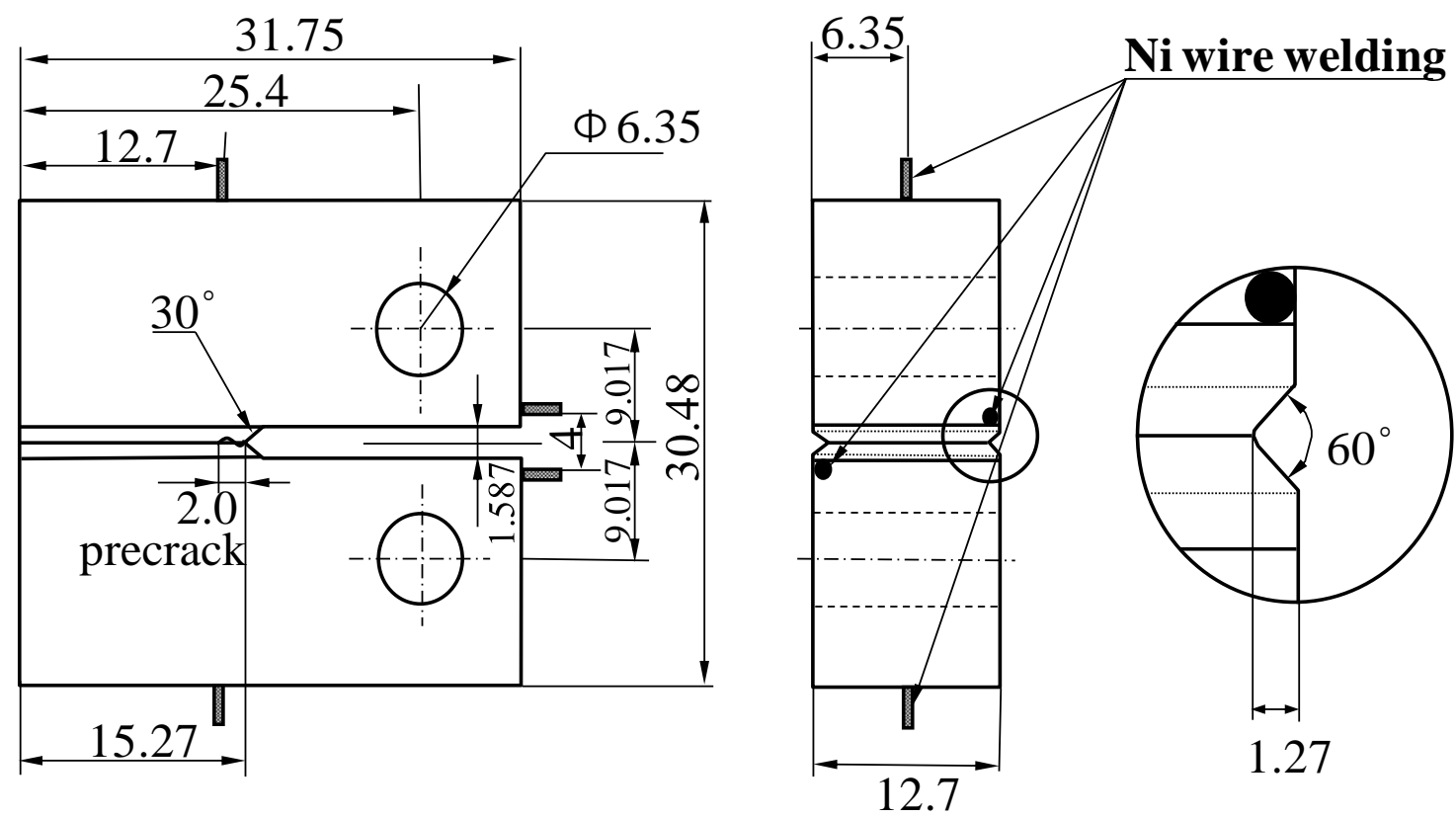
Gambar 2: Spesimen CT.

Metode NSW didasarkan atas pendekatan dimana area melar yang terdapat pada ujung area retakan dapat mewakili keseluruhan proses perambatan retak. Gambar 3 menunjukan skema ilustrasi dari area melar yang terdapat pada ujung retakan $\left(r_{c}\right)$. Penghitungan laju perambatan retak melar menggunakan metode NSW dibedakan menjadi dua berdasarkan regresi garis yang dilakukan pada kurva melar, yaitu laju regangan melar minimum dan rata-rata. Penggunaan laju regangan melar minimum digunakan dengan mengabaikan tahap pertama dan ketiga pada kurva melar. Pengabaian ini dilakukan dengan pertimbangan bahwa proporsi waktu pada tahap-tahap tersebut tidak terlalu signifikan [7-8]. Namun pada kasus-kasus tertentu, proporsi waktu pada tahap-tahap tersebut perlu dipertimbangkan, sehingga perlu dilakukan regresi secara keseluruhan mulai dari tahap satu, dua dan tiga pada kurva melar, atau disebut dengan laju regangan melar rata-rata. Penggunaan semua tahapan pada kurva melar akan memberikan sejumlah deviasi terhadap prediksi laju perambatan retak melar yang cukup besar apabila ternyata proporsi waktu pada tahap satu dan tiga cukup memberi kontribusi. Laju perambatan retak melar berdasarkan laju regangan melar minimum dan rata-rata dengan menggunakan pendekatan metode NSW dirumuskan masing-masing pada persamaan (3) dan (4) berikut [10-12]:

$$
\begin{aligned}
& \dot{a}_{S}^{N S W}=\frac{(n+1)}{e_{f}^{*}}\left[\frac{C^{*}}{I_{n}}\right]^{\frac{n}{n+1}}\left(A r_{c}\right)^{\frac{1}{n+1}} \\
& \dot{a}_{S}^{N S W}=\left(\frac{n+1}{n+1-v}\right)\left[\frac{C^{*}}{I_{n} \sigma_{0}}\right]^{\frac{v}{n+1}} \frac{r_{c}^{\frac{1}{n+1}}}{e_{f}^{*}}
\end{aligned}
$$

dimana $A$ dan $n$ adalah konstanta melar, $\sigma_{o}$ adalah tegangan normalising, $v$ adalah konstanta dari tempereture dependent, $r_{c}$ adalah area melar, dan $\varepsilon_{f}^{*}$ adalah nilai keuletan akibat melar. Nilai $I_{n}$ dibedakan berdasarkan kondisi plane stress dan strain yang merupakan fungsi dari konstanta melar, dimana masing-masing diperoleh berdasarkan persamaan(5) dan (6) berikut,

$$
\begin{gathered}
I_{n}=10.3 \sqrt{0.13+\frac{1}{n}}-\frac{4.6}{n} \\
I_{n}=7.2 \sqrt{0.12+\frac{1}{n}}-\frac{29}{n}
\end{gathered}
$$

Nilai $\varepsilon_{f}^{*}, \sigma_{o}, I_{n}, r_{c}$, dan $v$ untuk masing-masing data berdasarkan laju regangan melar minimum dan rata-rata untuk kondisi plane stress dan strain pada baja austenitik AISI 316L dirangkum dalam tabel 2.

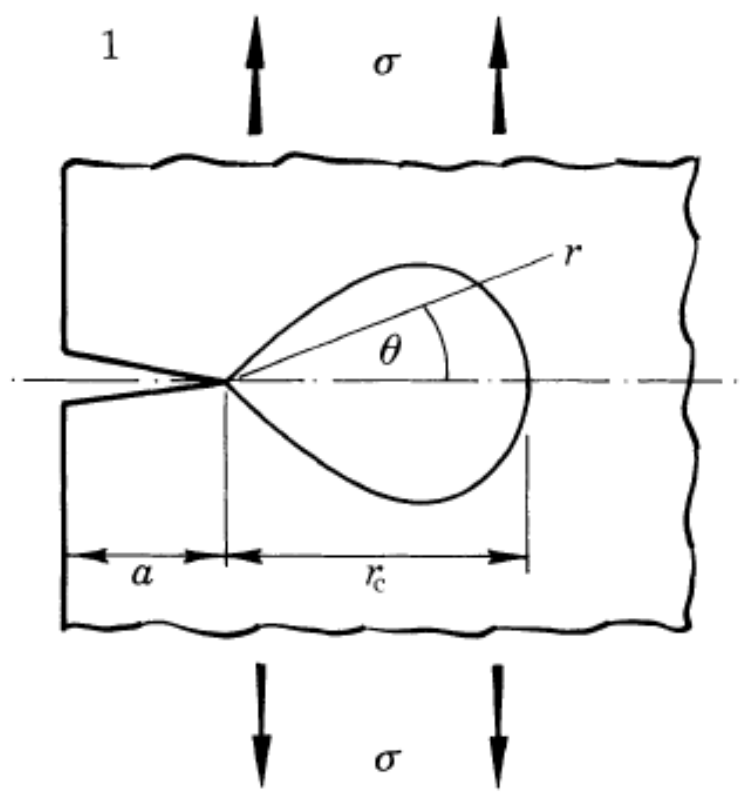

Gambar 3. Area melar. 


\section{HASIL DAN DISKUSI}

\subsection{Laju perambatan retak melar berdasarkan data pengujian perambatan retak melar}

Gambar 4 menunjukan kurva laju perambatan retak melar berdasarkan data pengujian perambatan retak melar untuk material AISI $316 \mathrm{~L}$ pada temperatur $525^{\circ} \mathrm{C}$ dengan beberapa variasi pembebanan konstan. Beberapa hasil penelitian telah melaporkan bahwa laju perambatan retak melar umumnya diawali oleh kurva non-linear pada tahap pertama atau yang sering disebut dengan istilah tail dan dilanjutkan oleh garis linear pada tahap kedua. Pada beberapa material, kurva non-linear tersebut memiliki porsi waktu melar yang cukup besar, sehingga diperlukan analisis lebih lanjut [7-8]. Dari gambar 4 terlihat bahwa kurva melar pada material AISI 316L diawali oleh tahapan pertama berupa kurva non-linear yang mengarah ke bawah. Kurva non-linear tersebut terjadi akibat kerusakan yang telah terakumulasi dan menumpuk di ujung titik retakan (crack tip) [17]. Namun dilihat dari porsi waktu proses melar yang terjadi, terlihat jelas bahwa tahapan pertama tidak terlalu signifikan dibandinkan tahapan kedua. Porsi waktu tahapan kedua yang berupa garis linear hampir mendominasi fenomena melar yang terjadi. Oleh sebab itu, prediksi laju perambatan melar hanya difokuskan pada tahapan kedua pada kurva melar.

Table 2: Nilai konstanta untuk prediksi perambatan retak melar menggunakan metode NSW.

\begin{tabular}{|c|c|c|c|c|}
\hline \multirow{2}{*}{} & \multicolumn{2}{|c|}{ Laju melar minimum } & \multicolumn{2}{c|}{ Laju melar rata-rata } \\
\cline { 2 - 5 } & Plane stress & Plane strain & Plane stress & Plane strain \\
\hline$n$ & 9.77 & 9.77 & 6.25 & 6.25 \\
\hline$A$ & $2.66 \mathrm{E}-27$ & $2.66 \mathrm{E}-27$ & $2.51 \mathrm{E}-17$ & $2.51 \mathrm{E}-17$ \\
\hline$\varepsilon_{f}^{*}$ & 1.50 & 0.05 & 1.50 & 0.05 \\
\hline$\sigma_{o}$ & 495 & 495 & 867 & 867 \\
\hline$I_{n}$ & 3.09 & 4.48 & 3.41 & 4.89 \\
\hline$r_{c}$ & 0.02 & 0.02 & 0.02 & 0.02 \\
\hline$v$ & & & 4.0568 & 4.0568 \\
\hline
\end{tabular}

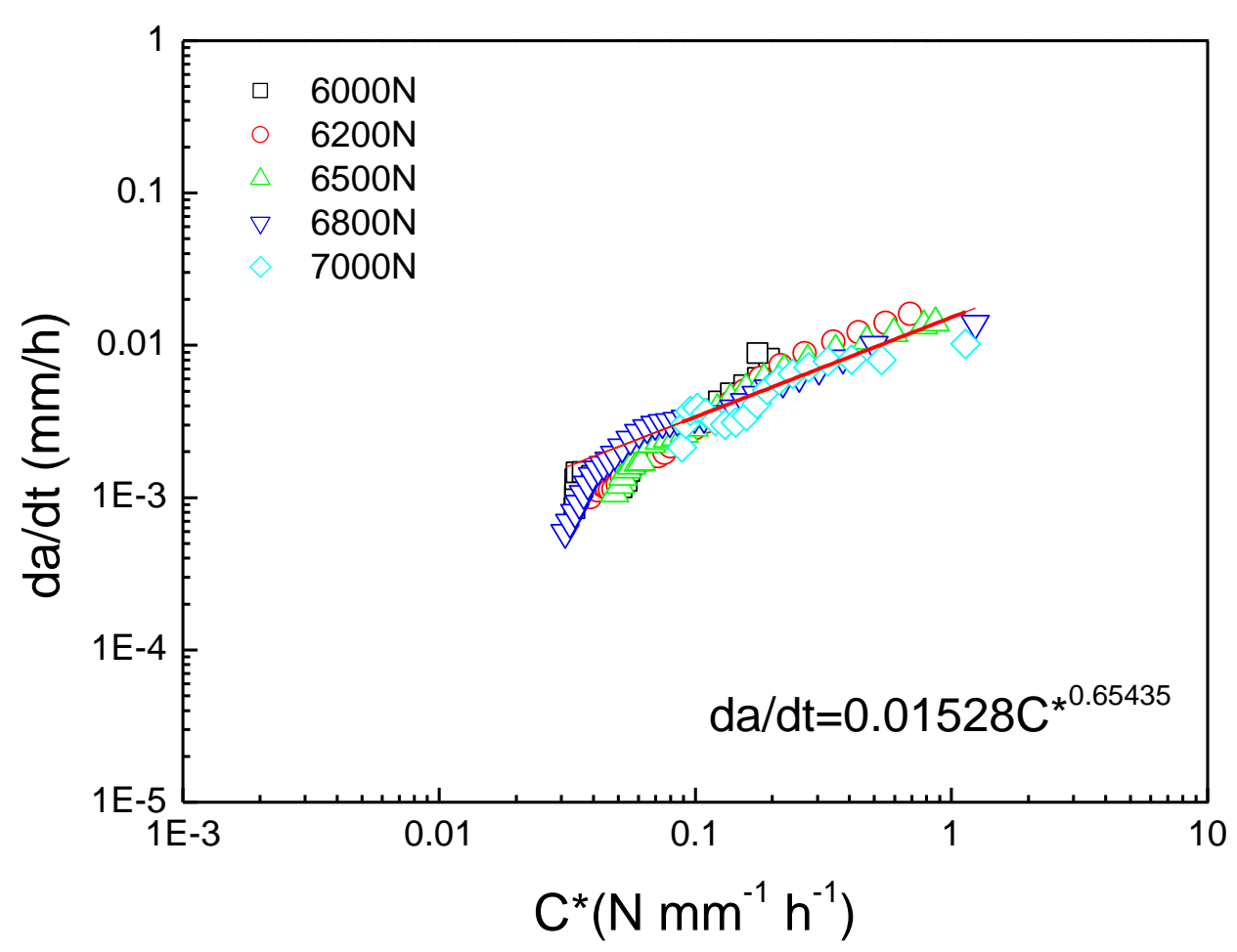

Gambar 4. Data pengujian perambatan retak melar. 
Garis regresi linear ditarik pada tahap kedua laju perambatan retak melar dan diperoleh persamaan laju perambatan retak melar terhadap parameter $C^{*}$ sebagai berikut:

$$
\frac{d a}{d t}=0.01528 C^{* 0.65}
$$

nilai konstanta $B$ dan $q$ masing-masing adalah 0.01528 dan 0.65 .

\subsection{Prediksi laju perambatan retak melar berdasarkan konstanta melar dan metode NSW}

Gambar 5 menunjukan perbandingan antara kurva prediksi laju perambatan retak melar terhadap kurva eksperimen laju perambatan retak melar. Garis tebal merah mewakili kurva eksperimen laju perambatan retak melar, sedangkan garis putus-putus menunjukan prediksi laju perambatan retak melar. Dengan menggunakan persamaan (2), diperoleh persamaan laju perambatan retak melar berdasarkan laju regangan melar minimum sebagai berikut,

$$
\begin{aligned}
& \frac{d a}{d t}=0.00228 C^{* 0.61} \\
& \frac{d a}{d t}=0.06834 C^{* 0.61}
\end{aligned}
$$

dimana persamaan (8) adalah laju perambatan retak melar minimum untuk kondisi plane stress dan persamaan (9) untuk kondisi plane strain. Sedangkan untuk laju perambatan retak melar berdasarkan laju regangan melar rata-rata dengan menggunakan persamaan (3), diperoleh sebagai berikut,

$$
\begin{aligned}
& \frac{d a}{d t}=0.00359 C^{* 0.91} \\
& \frac{d a}{d t}=0.07679 C^{* 0.91}
\end{aligned}
$$

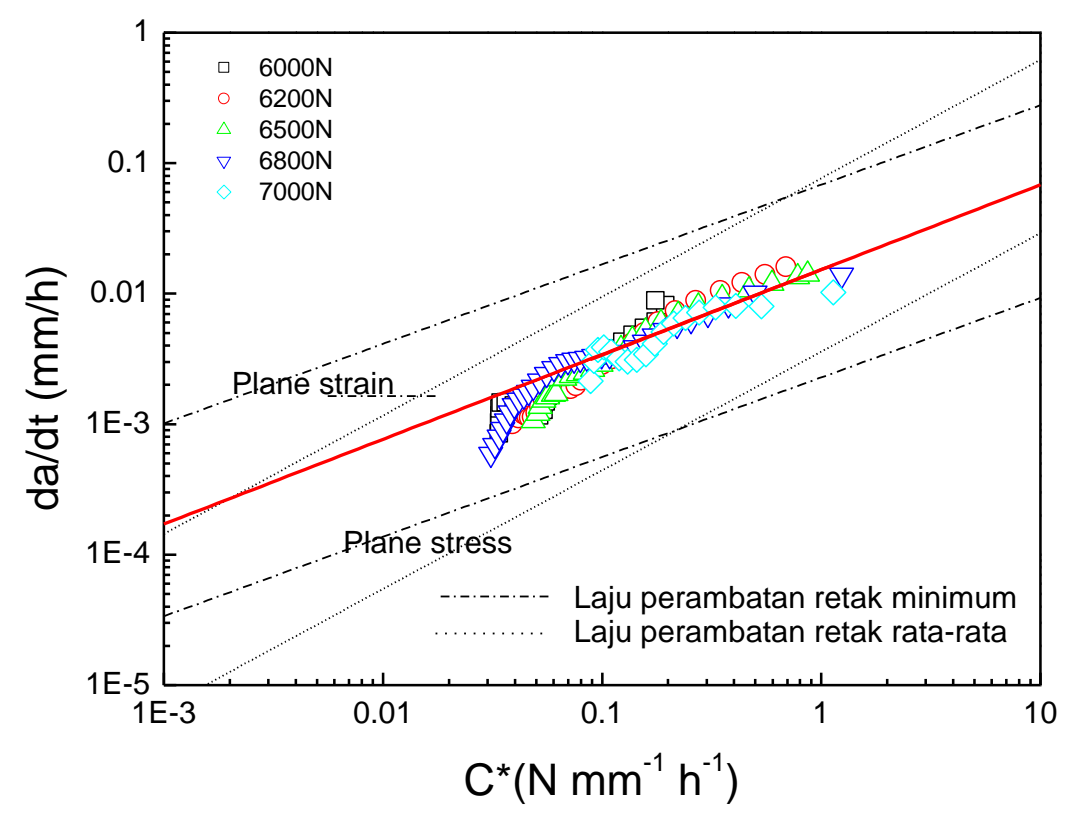

Gambar 5. Perbandingan antara laju perambatan retak melar prediksi dan eksperimen. 
dimana persamaan (10) adalah laju perambatan retak melar rata-rata untuk kondisi plane stress dan persamaan (11) untuk kondisi plane strain. Dari gambar 5 terlihat bahwa prediksi laju perambatan retak melar berdasarkan data laju regangan melar minimum memiliki nilai kemiringan kurva (slope) yang cenderung lebih dekat yaitu 0.61 dengan data pengujian perambatan retak melar yaitu 0.65 . Sedangkan untuk laju perambatan retak melar rata-rata, nilai $q$ cukup berbeda yaitu 0.91 . Nilai laju perambatan retak melar minimum mendekati data pengujian perambatan retak melar dikarenakan perambatan retak yang terjadi pada AISI $316 \mathrm{~L}$ sebagian besar waktu prosesnya terjadi pada tahap kedua. Sedangkan pada tahap pertama, porsi waktu untuk proses perambatan retak tidak terlalu signifikan, sehingga nilainya dapat diabaikan. Sehingga untuk data perambatan retak melar rata-rata terjadi deviasi yang cukup besar karena data yang digunakan menggunakan data regresi rata-rata keseluruhan tahapan pada kurva melar. Selanjutnya, dari gambar 4 terlihat bahwa perambatan retak yang terjadi berupa plane strain dimana nilai $B$ yaitu 0.06834 lebih dekat terhadap nilai $B$ yang diperoleh dari data pengujian perambatan retak melar yaitu 0.01528 . Perambatan retak melar berdasarkan plane strain mengindikasikan bahwa pada saat pembebanan, tidak terjadi deformasi pada arah lateral/ tegak lurus pembebanan.

\section{KESIMPULAN}

Dapat disimpulkan bahwa nilai konstanta melar yang diperoleh dari data pengujian melar dan dirumuskan menggunakan metode NSW dapat digunakan untuk memprediksi laju perambatan retak melar pada material AISI 316L. Penggunaan nilai konstanta yang diperoleh dari regresi garis pada kurva regangan melar minimum menghasilkan nilai yang lebih baik dibandingkan regresi garis pada kurva regangan melar rata-rata. Dari kurva pengujian laju perambatan retak melar, porsi tahapan laju perambatan retak melar sebagian besar terdapat pada tahap kedua. Dilihat dari kondisi tegangan permukaan, Laju perambatan retak pada material AISI 316L lebih mendekati kondisi plane strain.

\section{DAFTAR PUSTAKA}

[1] T. D. WIDODO., dan R. RAHARJO, "Pengaruh ball peening terhadap kekerasan baja tahan karat AISI 316L", Jurnal Rekayasa Mesin, v. 7, n. 3, pp. 151-155, Agustus 2018.

[2] M. PRAMUDIA, A.S. ROMADHON, "Pengaruh variasi ukuran bola baja pada proses dry shot peening terhadap mikrostruktur dan kekerasan material implan AISI 316L", Jurnal Rekayasa Mesin, v. 9, n. 3, pp. 169-172, Desember 2018.

[3] B. CAI, J.H. KANG, C.W. HONG, dan S.J. KIM, "Effects of N and Cu on the prediction of creep life of $316 \mathrm{~L}$ austenitic stainless steel at $650^{\circ} \mathrm{C} "$, Materials Sciences and Engineering: A, v. 662, pp. 198-203, 2016.

[4] V. GANESAN, M. D. MATHEW, P. PARAMESWARAN, dan K. LAHA, "Effect of nitrogen on evolution of dislocation substructure in 316LN SS during creep". Procedia Engineering, v. 55, pp. 36-40, 2013.

[5] M. D. MATHEW, K. LAHA, dan V GANESAN, "Improving creep strength of 316L stainless steel by alloying with nitrogen". J. of Material Science and Engineering A, v. 535, pp. 76-83, 2012.

[6] J. G. KUMAR, V. GANESAN, K. LAHA, dan M. D. MATHEW, "Time dependent design curves for a high nitrogen grade of 316LN stainless steel for fast reactor applications". J. of Nuclear Engineering and Design, v. 265, pp. 949-956, 2013.

[7] I.M.W. EKAPUTRA, WOO-GON KIM, JAE-YOUNG PARK, SEON-JIN KIM, dan EUNG-SEON KIM, "Characterization of the $Q^{*}$ parameter for evaluating creep crack growth rate for Type 316LN stainless steel". J. of Mechanical Science and Technology, v. 30 (7), pp. 1-8, 2016.

[8] I. M. W. EKAPUTRA, W. G. KIM, J. Y. PARK, S. J. KIM, dan Y. W. KIM, "Analysis of the creep crack growth rate for modified $9 \mathrm{Cr}-1 \mathrm{Mo}$ steel using $Q^{*}$ parameter". J. of Mechanical Science and Technology, v. 28, pp. 4075-4081, 2014.

[9] Y. KUMAR, S. VENUGOPAL, G. SASIKALA, P.K. PARIDA, dan A. MOITRA, "Study of creep crack growth behviour of a type $316(\mathrm{~N})$ stainless steel weld and its mechanism", Materials Sciences and Engineering, v. 731, pp. 551-560, 2018.

[10] S. LIU, G.Z. WANG, S.T. TU, dan F.Z XUAN, "Creep crack growth prediction and assessment incorporating constraint effect for pressurized pipes with axial surface cracks", Engineering Fracture Mechanics, v. 154, pp. 92-110, 2016.

[11] L. ZHAO, H. JING, Y. HAN, J. XIU, dan L. XU, "Prediction of creep crack growth behavior in ASME P92 steel welded joint", Computiational Materials Sciences, v. 61, pp. 185-193, 2012.

[12] D. WU, H. JING, L. XU, L. ZHAO, dan Y. HAN, "Enhanced model of creep crack initiation prediction coupled the stress-regime creep properties and constraint effect", European Journal of Mechnaics A/Solids, v. 74, pp. 145-159, 2019. 
[13] Y.C. ZHANG, W. JIANG, S. T. TU, X.C ZHANG, Y.J. YE, dan R.Z. WANG, "Experimental investigation and numerical prediction on creep crack growth behavior of the solution treated inconel 625 superalloy", v. 199, pp. 327-324, 2018.

[14] H.S. MA, G.Z. WANG, S. LIU, S.T. TU, dan F.Z. XUAN, "In-plane and out-of-plane unified constraintdependent creep crack growth rate of $316 \mathrm{H}$ steel”, Engineering Fracture Mechanics, v. 155, pp. 88-101, 2016.

[15] J.Z. HE, G.Z. WANG, S.T. TU, dan F.Z. XUAN, "Prediction of creep crack initiation behavior considering constraint effects for cracked pipes, Engineering Fracture Mechanics, v. 190, pp. 213-231, 2018.

[16] ASTM E 1457-15, Standard test method for measurement of creep crack growth rates in metals, (2015).

[17] R.A. AINSWORTH, High temperature component life assessment, 1ed., United Kingdom, Chapman\&Hall, 1994. 